\title{
Obituary
}

\section{Dr. Peter Fisher: An Enduring Force for Homeopathy}

\author{
Robert T. Mathie ${ }^{1}$ \\ ${ }^{1}$ Homeopathy Research Institute, London, United Kingdom \\ Homeopathy 2018;107:223-224.
}

But strew his ashes to the wind Whose sword or voice has served mankind,And is he dead, whose glorious mind Lifts thine on high?-

To live in hearts we leave behind Is not to die.

Thomas Campbell: Hallowed Ground (1825)

The world of homeopathy continues to mourn Peter Fisher's sudden death in a terrible road accident in August. Collectively and individually, we suffer the pain of losing homeopathy's most prominent opinion leader, the longest-standing Editor-in-Chief of this journal, and this year's President of the Faculty of Homeopathy. Medicine, more generally, has lost one of its most passionate and successful advocates for the integration of complementary and conventional treatments in individuals with chronic and complex health problems. His irreplaceable loss devastates his family and friends, and leaves bereft each and every one of us who works in the area of clinical or scientific homeopathy.

In the role now of Acting Editor of Homeopathy, I have been privileged to receive many heart-felt messages of reflection-from around the world-on Peter's passing. Typical of these are the following:

'It is difficult to imagine that [the news] is true, but it is in the papers so it has to be true, and we have to face the horrible truth.'

'What a tragedy. We have to work even more for homeopathy from now.'

'The news of the deadly cycling incident reached us this afternoon. It will be a huge loss for science and for homeopathy. He was a great fighter for quality in scientific research in homeopathy.'

'The loss of Peter must be hard for his family, and it is also tragic for homeopathy on so many levels. He has contributed more to homeopathy than most of us can dream of.'

'It is shocking that Dr. Peter Fisher is no more. It is a great loss to the homeopathic fraternity. Currently, when homeo- pathy is going through a historical low, his presence was all the more required.'

'Dr. Peter Fisher's passing is a sad loss for homeopathy. His desire to give a solid evidence base to homeopathy

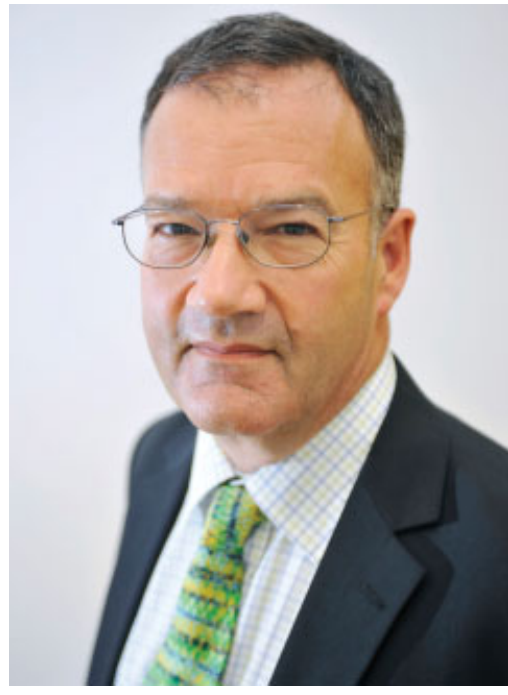

Dr. Peter Fisher shone through in his writings that I was privileged to read.'

'We are all deeply saddened to hear about the sudden death of Dr. Peter Fisher. He was really an icon in the field of homeopathy.'

'The best thing that can happen out of this tragedy is for homeopathy to re-launch and become the real co-ordinated international force for health and good that we know it can and should be.'

As emphasised by these comments, Peter's positive influence in homeopathy is unsurpassed. His personal approach is rightly summarised in the $B M J$ as a 'single-minded determination to promote homeopathy' despite the 'criticism and scientific evidence against it.. ${ }^{1}$ He was always the first person to be contacted when a public rebuttal was required for a newly published article or commentary disparaged homeopathy and its clinical effectiveness. A clinician by training, Peter's comprehensive grasp of fundamental scientific evidence in homeopathy was also second to none: his editorship of this journal-over an unprecedented 32 years-provided many sources of reference for that wealth of ready knowledge.

Peter's own published record is impressive, including more than 100 articles indexed in PubMed. Amongst these are: his clinical trials on homeopathy for fibromyalgia and for rheumatoid arthritis; 2,3 a patient-reported outcomes survey from the Royal London Homeopathic Hospital; ${ }^{4}$ three Cochrane reviews; ${ }^{5-7}$ a review of the international clinical trial literature in homeopathy; ${ }^{8}$ and work on the homeopathic 'model validity' of clinical trials, ${ }^{9}$ undertaken during his chairmanship of the International Scientific Committee
Copyright $\odot 2018$ The Faculty of Homeopathy
DOI https://doi.org/ 10.1055/s-0038-1675185. ISSN 1475-4916. 
for Homeopathic Investigations. Other topics of profound importance to him are developed in Peter's articles on 'plausibility bias' ${ }^{10}$ and 'effectiveness gaps'11 (terms that he invented and championed), and in an opinion-piece on polypharmacy and multi-morbidity. ${ }^{12}$ Together with his many thoughtful and thought-provoking editorials for this journal, including a recent piece on the problem of antimicrobial resistance, ${ }^{13}$ and his written responses to negatively critical articles and commentaries elsewhere, it is selfevident that Peter's impact on homeopathy is indelibly imprinted in the published literature.

This enduring contribution, alluded to also in the above personalised comments from colleagues and friends worldwide, is a basis for hope and confidence in homeopathy's clinical and scientific future beyond the tragic ending of Peter's life. Those he leaves behind can-and we must-build on his striking example, ensuring that the force of his singular commitment to homeopathy does not die.

\section{Biography}

Peter Antony Goodwin Fisher, FFHom, FRCP.

Born, September 2, 1950, in Rotterdam, The Netherlands. Educated, Tonbridge School and Emmanuel College, Cambridge, United Kingdom.

Research Fellow, Department of Rheumatology, St Bartholomew's Hospital, London.

Research Director and previously also Clinical Director, Royal London Hospital for Integrated Medicine (formerly, Royal London Homeopathic Hospital).

Member, Expert Advisory Panel on Traditional and Complementary Medicine, World Health Organization.

Chair, International Scientific Committee for Homeopathic Investigations (ISCHI), 2005 to 2013.

Editor-in-Chief, Homeopathy, from 1986.

Homeopathic physician to Her Majesty Queen Elizabeth II, from 2001.

President, Faculty of Homeopathy, from March 2018.
Keenly interested in music, art, philosophy, gardening. Died, August 15, 2018, in a cycling accident in Holborn, London.

\section{References}

1 Illman J. Peter Fisher: homeopathic physician to the Queen. BMJ 2018;362:k3611

2 Fisher P, Greenwood A, Huskisson EC, Turner P, Belon P. Effect of homeopathic treatment on fibrositis (primary fibromyalgia). BMJ 1989;299:365-366

3 Fisher P, Scott DL. A randomized controlled trial of homeopathy in rheumatoid arthritis. Rheumatology (Oxford) 2001;40: 1052-1055

4 Sharples FM, van Haselen R, Fisher P. NHS patients' perspective on complementary medicine: a survey. Complement Ther Med 2003; 11:243-248

5 McCarney R, Warner J, Fisher P, Van Haselen R. Homeopathy for dementia. Cochrane Database Syst Rev 2003:CD003803

6 Kassab S, Cummings M, Berkovitz S, van Haselen R, Fisher P. Homeopathic medicines for adverse effects of cancer treatments. Cochrane Database Syst Rev 2009:CD004845

7 Mathie RT, Frye J, Fisher P. Homeopathic Oscillococcinum ${ }^{\circledR}$ for preventing and treating influenza and influenza-like illness. Cochrane Database Syst Rev 2015:CD001957

8 Mathie RT, Hacke D, Clausen J, Nicolai T, Riley DS, Fisher P. Randomised controlled trials of homeopathy in humans: characterising the research journal literature for systematic review. Homeopathy 2013;102:3-24

9 Mathie RT, Roniger H, Van Wassenhoven M, et al. Method for appraising model validity of randomised controlled trials of homeopathic treatment: multi-rater concordance study. BMC Med Res Methodol 2012;12:49

10 Rutten L, Mathie RT, Fisher P, Goossens M, van Wassenhoven M. Plausibility and evidence: the case of homeopathy. Med Health Care Philos 2013;16:525-532

11 Fisher P, van Haselen R, Hardy K, Berkovitz S, McCarney R. Effectiveness gaps: a new concept for evaluating health service and research needs applied to complementary and alternative medicine. J Altern Complement Med 2004;10:627-632

12 Jacobs J, Fisher P. Polypharmacy, multimorbidity and the value of integrative medicine in public health. Eur J Integr Med 2013;5:4-7

13 Fisher P. Homeopathy and antimicrobial resistance. Homeopathy 2014;103:95-96 